\title{
NON-POLLEN PALYNOMORPHS FROM MID-HOLOCENE PEAT OF THE RAISED BOG BORSTELER MOOR (LOWER SAXONY, GERMANY)
}

\author{
Lyudmila S. Shumilovskikh ${ }^{1,2,3}$, Frank Schlütz ${ }^{4}$, Inke Achterberg ${ }^{3}$, Andreas Bauerochse, \\ Hanns Hubert Leuschner ${ }^{3}$
}

${ }^{1}$ Mediterranean Institute of Marine and Terrestrial Biodiversity and Ecology, IMBE UMR CNRS 7263, Europôle Mediterraneen de l'Arbois, 13545 Aix-en-Provence, France; lyudmila.shumilovskikh@imbe.fr ${ }^{2}$ Laboratory of Biogeochemical and Remote Methods of Environmental Monitoring, National Research Tomsk State University, Russia; shumilovskikh@yahoo.com

${ }_{3}^{3}$ Department of Palynology and Climate Dynamics, Georg-August-University of Göttingen, Göttingen, Germany; Inke.Achterberg@biologie.uni-goettingen.de; hleusch@gwdg.de

${ }_{5}^{4}$ Lower Saxony Institute for Historical Coastal Research, Wilhelmshaven, Germany; schluetz@nihk.de

${ }^{5}$ Lower Saxony State Service for Cultural Heritage, Hanover, Germany;

andreas.bauerochse@nld.niedersachsen.de

\begin{abstract}
In order to reconstruct regional vegetation changes and local conditions during the fen-bog transition in the Borsteler Moor (northwestern Germany), a sediment core covering the period between 7.1 and 4.5 cal kyrs BP was palynologically investigated. The pollen diagram demonstrates the dominance of oak forests and a gradual replacement of trees by raised bog vegetation with the wetter conditions in the Late Atlantic. At $\sim 6$ cal kyrs BP, the non-pollen palynomorphs (NPP) demonstrate the succession from mesotrophic conditions, clearly indicated by a number of fungal spore types, to oligotrophic conditions, indicated by Sphagnum spores, Bryophytomyces sphagni, and testate amoebae Amphitrema, Assulina and Arcella, etc. Four relatively dry phases during the transition from fen to bog are clearly indicated by the dominance of Calluna and associated fungi as well as by the increase of microcharcoal. Several new NPP types are described and known NPP types are identified. All NPP are discussed in the context of their palaeoecological indicator values.
\end{abstract}

Key words: pollen, fungal spores, microbiomorphs, palynology, bog development.

Manuscript received 7 November 2014, accepted 8 June 2015

\section{INTRODUCTION}

The Borsteler Moor (Lower Saxony, Germany) is a typical raised bog of the northwestern German Plain (Fig. 1). Until drainage in $19^{\text {th }}$ and $20^{\text {th }}$ centuries, this area was a vast peat-dominated landscape. About one third of the lowland area between the North Sea coast and the Central Uplands had been covered by raised bogs up to $10 \mathrm{~m}$ in height (Behre 2008; Grosse-Brauckmann 1997). These abundant raised bogs had developed from former fens or directly on nutrient-poor glacial sands particularly since about 9 kyrs BP due to a rapid increase of the sea-level (Behre 2004; Eckstein et al. 2011). Such remarkable landscape changes influenced vegetation successions and vegetation cover in the region.

Within the project "Dendroecological studies of subfossil pine-forests in Lower Saxony", the Borsteler Moor was studied in order to investigate the transition from fens to Sphagnum bogs in this region. Dendrochronological studies clearly reveal several establishment and dying-off phases of pines in the raised bog (ongoing study), raising the question of whether the transition to Sphagnum bog was gradual or interrupted by dry phases, requiring further palaeoenvironmental reconstructions of bog development. Therefore, a section from the early formation of the Borsteler Moor raised bog was palynologically investigated in order to reconstruct the local development during the fen-bog transition. For this, locally produced microscopic plant, fungal and animal remains, known as non-pollen palynomorphs (NPP), are very suitable (e.g. Hesmer 1929; Frey 1964; van Geel 1978) and often better than pollen, as this can be transported over long distances. Numerous studies of NPP from raised bog profiles in the Netherlands and northern Germany (e.g. van Geel 


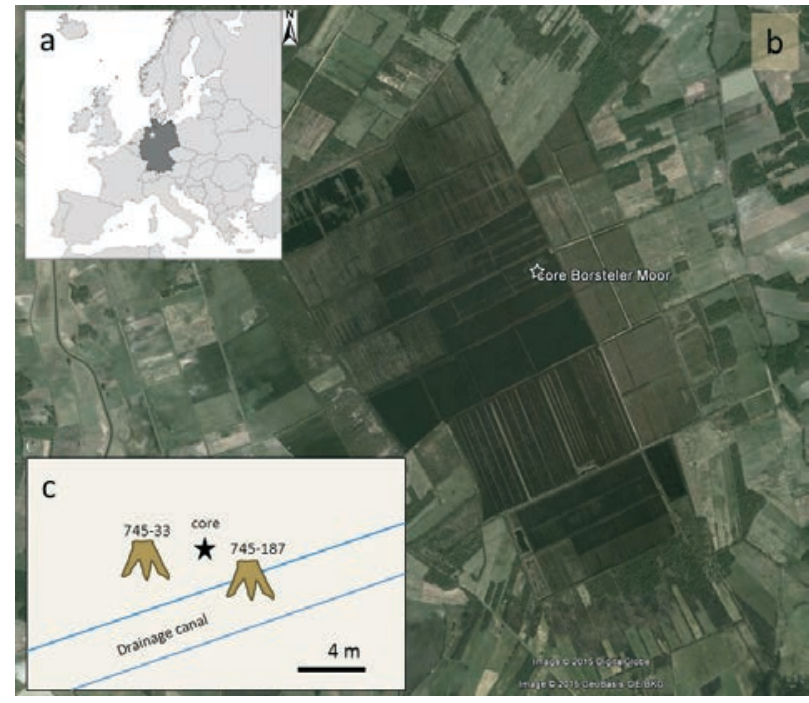

Fig. 1. Location of the Borsteler Moor core (star). a) map of Europe with Germany and position of the Borsteler Moor; b) Google Earth map of the Borsteler Moor; c) schematic diagram of location of the core and pine root plates used for establishment of the age-depth model.

1978; Kuhry 1985; Blaauw, Mauquoy 2012) have demonstrated the usefulness of these microfossils in the reconstruction of local hydrological conditions, nutrient status, and diseases of plants or fungi. In this paper we provide the results of the palynological investigation of the Borsteler Moor with special emphasis on NPP.

\section{MATERIAL AND METHODS}

Peat coring was carried out in the Borsteler Moor in June 2013. The coring site $\left(52^{\circ} 38^{\prime} 19.73^{\prime \prime} \mathrm{N}, 8^{\circ} 58^{\prime} 19.49^{\prime \prime} \mathrm{E}, 36.21\right.$ $\mathrm{m}$ a.s.1.) was chosen on a peat surface exposed by peat extraction close to in situ pine root plates needed for additional age control. Coring was performed with a Gouge corer (coring chamber $100 \mathrm{~cm})$ on the same position in two sections $(0-87$ $\mathrm{cm}$ and $87-116 \mathrm{~cm})$. The upper $13 \mathrm{~cm}$ were not collected be-

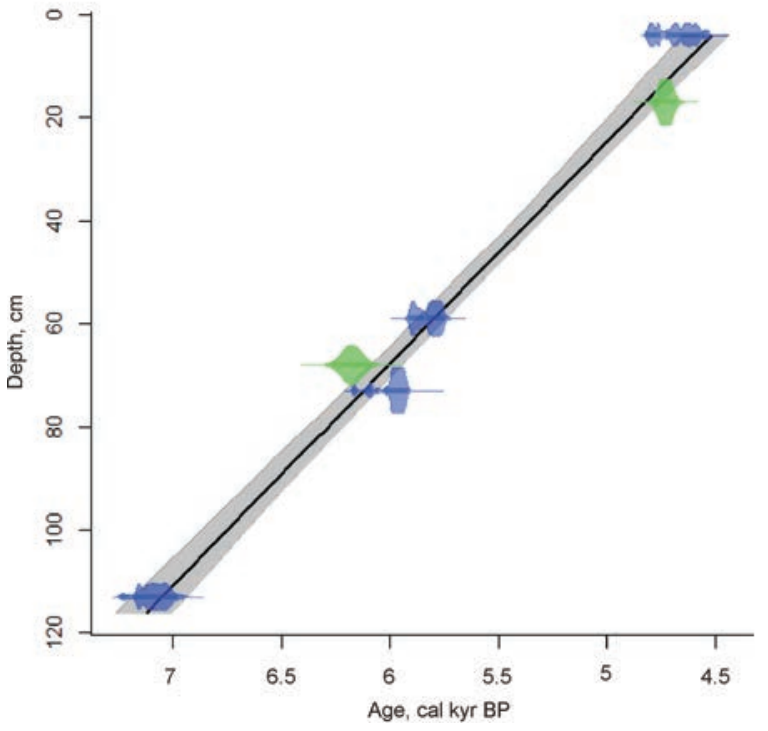

Fig. 2. Age-depth model of the Borsteler Moor based on radiocarbon dating of peat bulk (blue) and dendrochronological dating (green).

cause of the visible mixing, therefore a zero depth of the core is located $13 \mathrm{~cm}$ under the surface. Geographical coordinates were taken with Leica GNSS System, Antenna GS 15 and Handheld CS 15 with Satellite Reference of Ascos (error estimates $\pm 2 \mathrm{~cm})$.

\section{Age-depth model}

The age-depth model for the Borsteler Moor core is based on two dendrochronological and four radiocarbon dates (Table 1, Fig. 2). For the dendrochronological control, pines $745-33\left(52^{\circ} 38^{\prime} 19.69^{\prime \prime} \mathrm{N} 8^{\circ} 58^{\prime} 19.28 \mathrm{E}\right.$; $35.40 \mathrm{~m}$ a.s.1.) and 745-187 (52 $38^{\prime} 19.66^{\prime \prime} \mathrm{N} 8^{\circ} 58^{\prime} 19.65 " \mathrm{E}$; $35.91 \mathrm{~m}$ a.s.1.) were dated by H. Leuschner (Göttingen) to the age of 62236130 and 4760-4702 cal yr BP (year 1950 as the present), respectively. Based on the GPS coordinates and field observa-

Chronological control of the peat core from Borsteler Moor

\begin{tabular}{|c|c|c|c|c|c|}
\hline Core depth, $[\mathrm{cm}]$ & Dating method & Dated material & Lab. No. & Age ${ }^{14} \mathrm{C}$ yrs BP & Age cal yrs BP (probability) \\
\hline $4-5$ & AMS ${ }^{14} \mathrm{C}$ & peat bulk & Poz-60932 & $4130 \pm 30$ & $\begin{array}{c}4533-4544(2.1) \\
4546-4558(2.3) \\
4567-4728(63.2) \\
4738-4740(0.4) \\
4750-4820(26.9)\end{array}$ \\
\hline $17_{\text {estimated }}$ & dendrochronology & pine tree-rings & M745-187 & - & $4760-4702$ \\
\hline $59-60$ & AMS ${ }^{14} \mathrm{C}$ & peat bulk & Poz-60933 & $5090 \pm 35$ & $\begin{array}{l}5747-5833(57.3) \\
5840-5913(37.5) \\
\end{array}$ \\
\hline $68_{\text {estimated }}$ & dendrochronology & pine tree-rings & M745-33 & - & $6223-6130$ \\
\hline $73-74$ & AMS ${ }^{14} \mathrm{C}$ & peat bulk & Poz-60934 & $5225 \pm 35$ & $\begin{array}{c}5912-6023(82.5) \\
6053-6061(0.9) \\
6079-6113(7.6) \\
6154-6174(3.9) \\
\end{array}$ \\
\hline $113-114$ & AMS ${ }^{14} \mathrm{C}$ & peat bulk & Poz-60935 & $6190 \pm 40$ & $\begin{array}{c}6977-7179(90.2) \\
7198-7238(4.8)\end{array}$ \\
\hline
\end{tabular}


tions, the positions of the pine root plates were estimated at 68 and $17 \mathrm{~cm}$ depth of the Borsteler Moor core, respectively. For AMS radiocarbon dating, four bulk samples of one-centimeter thickness were analyzed at the Poznań Radiocarbon Laboratory. As the core was taken from the (vegetation-free) freshly cut peat several meters below the former bog surface, the risk of erroneously young radiocarbon dates caused by modern roots was excluded. The age-depth model (Fig. 2) was conducted within the free R package CLAM (Blaauw 2010) applying the implemented linear regression model to all age and depth data (Table 1). For the age-depth model, the radiocarbon age calibration curve IntCal13 was used (Reimer et al. 2013) and calculations were made using 95\% confidence ranges. All ages given in the text are calibrated data.

\section{Palynological investigations}

In total, 45 subsamples of one $\mathrm{cm}^{3}$ were collected from the Borsteler Moor core at intervals of $2 \mathrm{~cm}$ in the upper part $(0-64 \mathrm{~cm})$, and $4-6 \mathrm{~cm}$ in the lower part $(64-116 \mathrm{~cm})$. The subsamples were treated with cold $10 \% \mathrm{HCl}$ and acetolysis with sieving using metal sieve with a $200 \mu \mathrm{m}$ mesh size. In order to calculate concentrations, two tablets of Lycopodium spores (Batch number 1031) were added at the beginning of treatment. Prepared subsamples were stored in glycerin. Sums of total pollen grains counted up to a minimum of 1000 grains were used to calculate the percentages of pollen and NPP. Pollen identification and taxonomy follows Beug (2004). NPP identification is based on van Geel (1978, 1981), Bakker, van Smeerdijk (1982) and Kuhry (1985). In the palynological diagram and the discussion, the identified NPP taxa are given taxonomical names, whereas the naming of unidentified NPP taxa follows Miola (2012). New NPP types are described with taxonomical names or using the abbreviation BM (Borsteler Moor) with a number. The diagram (Fig. 3) was constructed using C2 version 1.5 (Juggins 2007). Pollen zonation was carried out visually based on changes in dominant pollen, spores and NPP taxa. NPP are presented following their indicator value for the nutrient status as well as for wet and dry phases (van Geel 1978; Kuhry 1985; van Geel, Aptroot 2006). Supplementary data are available at doi:10.1594/PANGAEA.846695.

\section{RESULTS AND INTERPRETATION}

\section{NPP types}

The majority of NPP types in the present study were identified following van Geel (1978) and Kuhry (1985). These NPP are briefly summarized in this section, emphasizing their ecological interpretation with regard to the Borsteler Moor environment. The description of new NPP types (pollen infected by dark-coloured hyphae, pollen with sporangia of chytridiomycetes, BM-1, BM-2, BM-3, Dictyosporium australiense $=\mathrm{BM}-4$, Zygospores of Mucor $=\mathrm{BM}-5)$, the taxonomic identification of types with existing descriptions, and the discussion of their ecology as well as the microphotographs presented are arranged by organismic groups and morphology with animal remains followed by plant remains, NPP of unknown origin and then by fungal remains and spores arranged by their number of cells.

\section{1) Animal remains}

Testate amoebae are represented by Amphitrema flavum Archer 1842, Assulina muscorum Greeff 1888 and Arcella sp. (Fig. 4A, C, D). A. flavum is an indicator of actively growing Sphagnum bogs (Frey 1964). Maxima in the Borsteler Moor coincide with wet Sphagnum-phases (Fig. $3 \mathrm{~b})$. Interestingly, the highest maximum of A. flavum (30\%) occurred during the first Sphagnum phase. In the following Sphagnum phases, the amount of $A$. flavum does not exceed 4\%, in contrast to A. muscorum and Arcella spp. Since Arcella species are not sphagnophilous and can live in different mosses (Frey 1964), such a mixed assemblage might indicate drier or more nutrient-rich conditions.

Loricae of the rotifer Habrotrocha angusticolis (Murray) (Fig. 4B) are common in Sphagnum peat bogs (Frey 1964) and other mossy (Warner, Chengalath 1988) and wet habitats (van Geel 1978 in Borradaile et al. 1963). However, most of its palaeorecords are from Sphagnum peat, possibly due to good preservation under acid conditions (Frey 1964). A strong correlation of $H$. angusticollis and Sphagnum mosses was recently reported from a peat bog from NE Iran, connected with the discovery of subfossil remains of Sphagnum squarrosum, which was documented for the first time in Iran (Kürschner et al. 2015). A recent study of rotifer communities in peat bogs of Poland (Bielańska-Grajner et al. 2011) demonstrate that the presence of $H$. angusticolis correlates positively with the total organic content and nitrate. In the Borsteler Moor, H. angusticollis is characteristic for the wet phases, mostly coinciding with maxima of Sphagnum spores, the Sphagnum parasite Bryophytomyces sphagni and testate amoebae.

Copepod spermatophores (Fig. 4E) are well-known from peat (e.g. Rudolph 1917, Hesmer 1929, Frey 1964, van Geel 1978). Hesmer (1929) found the copepod Canthocamptus with spermatophores inside and provided the first description of this palynomorph. He stated that other copepods might have similar spermatophores and later authors list them as spermatophores of (harpacticoid) copepods (Frey 1964). Due to the lifecycle of copepods, their spermatophores are indicators for the (temporary) presence of open water (van Geel 1978). In the Borsteler Moor, spermatophores occur first in the mesotrophic swamp (zone Borstel-2), and increase during Sphagnum peat development (zone Borstel-4) but show maxima during the first two dry phases. Together with Rhabdocoela cocoons they nevertheless indicate open water at the site (Hesmer 1929).

\section{2) Plant remains}

Pollen infected by dark-coloured hyphae (Fig. 4G, H) are pollen grains, the apertures and/or insides of which are covered by dark-coloured fungal hyphae or are filled by pigmented fungal spores. The observed hyphae are concentrated in the aperture areas. In Angiosperm pollen, these are pores and colpi (Fig. 4G), thin regions in the pollen wall supposed to be passed by the germination tube and therefore not entirely covered by the very inert sporopollenin layer of the outer pollen wall (Punt et al., 2007). In the gymnosperm pollen, aperturoid areas and major occurrence of hyphae are located at the distal side between the two air-sacs of the pollen 


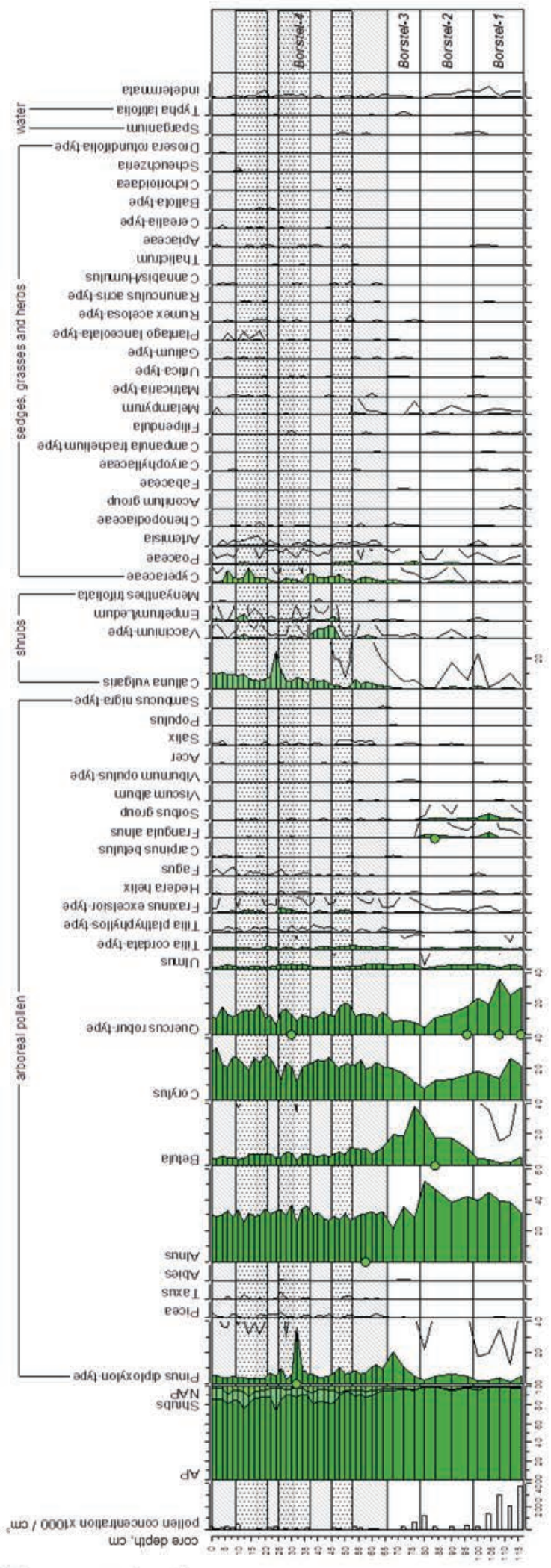

ธิ

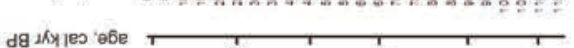

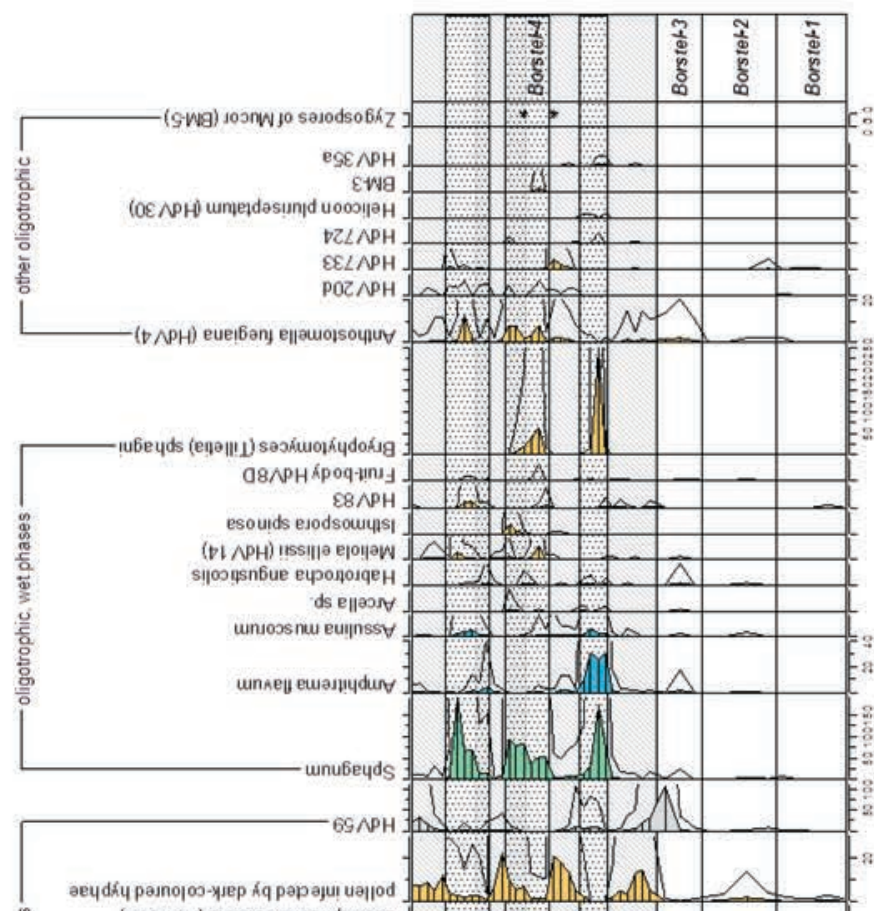

$(\mathrm{VEg} \wedge \mathrm{PH})$ ejepnes euaeydsorseา

(e $\angle L \mathrm{NPH}$ ) unnuydoubeyds unssoj6oag .

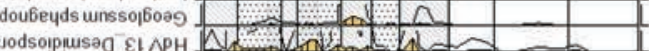

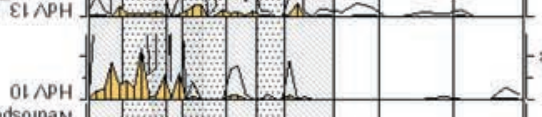

(OSS NPH) essero ejodsoman

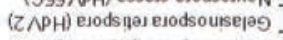

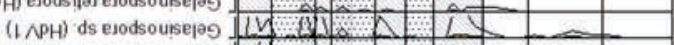

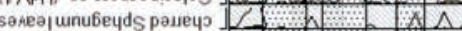

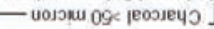
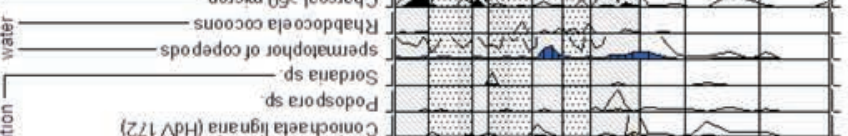

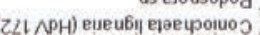

ds esoudosiaj

ejodsopann

- adরi-erumand ajodsoyna|a!

(tt $\wedge \mathrm{PH})$ adá-elsnap eu!nis

(tWG) asuejegsne unuodsoKp! (09ع $\mathrm{NPH})$ unjodsi|npuad unuods

$\left(Z 9 b^{\prime} 69 \varepsilon \wedge \mathrm{PH}\right)$ !uex olqp unyods ḱperg $\varepsilon 9 \mathrm{VPH}]$

ds aqroou p $59 \varepsilon \wedge \mathrm{PH}$

(81-gai) ejodsiano eiodsopod

(19V $\mathrm{NPH})$ ejeydaosaeyds ejodsouabony

ds eiçu|

ds əqณวับ $P 99 \mathrm{NPH}$

$99 \mathrm{NPH}$

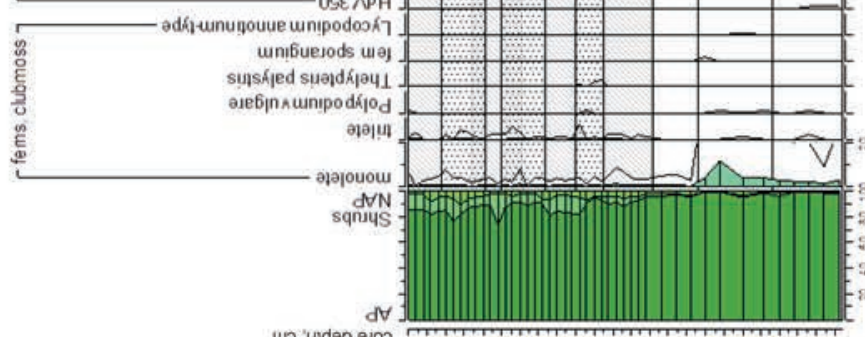

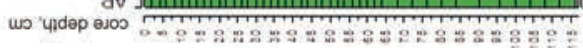

dg 2 firles abe T

e.

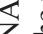

อี่

몽

퓬

을

\&

究

잌.

ज

응

낭 흠

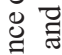

๑

․ㅡㄹ

苂

究

$\Xi 3$

के

글

घ

윰

范

एै

:

ธั่

$\stackrel{8}{\Sigma}$.

ฮี

要

宽

急

至

틀

.ํㅣ융

学

욜

륭 흐

ป.

을

里

응

흥 สี

怘

줄

호 옹

एँ

เิ

일

를

के ठे

क.

कิ 
grains (Fig. 4H). Pollen infected by dark-coloured hyphae, described here for the first time, occur mainly during the dry phases, suggesting increased saprotrophic activity of fungi.

Other pollen grains contain hyaline spheroid to prolongate objects in some cases connected to the inner pollen wall (Fig. 4I). We have identified these objects as pollen with sporangia of chytridiomycetes (e.g. Braune et al. 1999). Chytridiomycetes are well-known parasites of pollen grains, belonging to the Oomycetes. In the palynological literature, Hesmer (1929) documented and identified remains of chytridiomycete sporangia of Olpidium pendulum and other unidentified taxa in Pinus and Picea pollen grains for the first time. Although spores with chytrid sporangia occurred rather frequently in the Borsteler Moor, they were not counted and their palaeoecological meaning remains unclear until further investigations are carried out.

Charred fragments of Sphagnum leaves (Fig. 4F) with clearly visible former chlorophyll and hyaline (water-) cells occur during dry phases of bog development (Fig. 3).

\section{3) NPP of uncertain origin}

BM-1 (Fig. 4J, K, L) is globose, hyaline with an inner diameter of 30-32 $\mu \mathrm{m}$ and with bent protuberances of 3-4 $\mu \mathrm{m}$ length and $<1 \mu \mathrm{m}$ thickness, arranged 3-4 $\mu \mathrm{m}$ from each other. The protuberances are covered by a hyaline undulated membrane. BM-1 occurs mostly during the mesotrophic and rarely under dry oligotrophic conditions.

Globose hyaline microfossila of 24-30 $\mu \mathrm{m}$ diameter with curved protuberances of 3-8 $\mu \mathrm{m}$ (Fig. 4M, N) found here are similar to $\mathbf{H d V} \mathbf{5 9}$, described from sandy subsoil below peat (van Geel 1978). Bakker, van Smeerdijk (1982) found HdV 59 mainly in oligo- to ombrotrophic peat. In the Borsteler Moor, HdV 59 clearly corresponds to dry phases of oligotrophic peat. Possibly it is a moss spore.

HdV 35 is a globose or oval structure fractured in a pentagonal or hexagonal pattern with an overall diameter of 30-55 $\mu \mathrm{m}$ (van Geel 1978). In the Borsteler Moor, HdV 35 was found at the beginning of oligotrophic conditions. The palaeoecological meaning is uncertain; possibly of animal origin.

\section{4) Fungal remains}

Fruiting-bodies of HdV 8D (Fig. 5A) were originally found attached to the epidermis of Trichophorum caespitosum and on a leaves of Sphagnum section Cymbifolia (van Geel 1978). In the Borsteler Moor, HdV 8D is clearly associated with wet Sphagnum phases.

HdV 13 (Fig. 5B; van Geel 1978) was first found attached to the leaves of Polytrichum alpestre, Aulacomnium palustre, Scheuchzeria palustris, Calluna vulgaris, and Andromeda polifolia as well as inside the water-cells of Sphagnum imbricatum leaves (van Geel 1978). Van Geel (1978) conclude that HdV 13 might represent sporangia of $\mathrm{cf}$. Entophlyctis lobata Willoughby \& Townley (Chytridiales), agreeing with a previous identification of similar microfossils of Eocene age by Bradley (1967). Sherwood-Pike (1988) doubts this identification as well as the hypothesis of a hyphopodia origin, and suggests that this problematic microfossil might be a structure formed during germination of a sin- gle propagule. For example, germinating spores of Colletotrichum form short hyphae with dark thick-walled apressorium or conidia of Desmidiospora myrmecophila Thaxt. (Sherwood-Pike 1988). Following Kalgutkar, Jansonius (2000), we name this type Desmidiospora. However, this microfossil type remains problematic. Like other records (van Geel 1978, Kuhry 1997), in the Borsteler Moor the type is characteristic for oligotrophic stages especially during dry phases.

Hyaline spores with typical protuberances (Fig. 5C) were described as HdV 66 (van Geel 1978). Van Geel (1978) notes that HdV 66 includes smaller specimens of 19-21 $\mu \mathrm{m}$ with 8 or 12 protuberances and bigger ones of 30-34 $\mu \mathrm{m}$ with about 8 protuberances. We found the smaller ones. Van Geel (1978) reports HdV 66 from mesotrophic conditions and absent in oligotrophic Sphagnum peat. However, we found single spores during the mesotrophic stage and during the dry phase of oligotrophic stage. In contrast to the suggestion that HdV 66 might be zygospores of Penium (Desmidiaceae) (van Geel 1978), it seems very likely that they are basidiospores of some Inocybe species.

Bryophytomyces sphagni (Navashin) Cif. (formerly Tilletia sphagni) (Fig. 5D) is a pathogen ascomycete (Helotiaceae, Helotiales) on Sphagnum (Bauch 1938, Eckblad 1975). B. sphagni produces its anamorph spores within the Sphagnum sporophyte capsules, replacing the moss spores and using the explosive dispersal mechanism of the capsules for its own spreading (Davey, Currah 2006). The fungus parasitizes $S$. capillifolium, $S$. central, $S$. cuspidatum, $S$. recurvum, S. russowii, S. squarrosum and S. teres (Chau 1979). The globose B. sphagni spores with a typical channel-like reticulum are well-known objects from Holocene peats. Van Geel (1978, HdV 27) states that the spores do not correlate with species of Sphagnum sect. Acutifolia such as S. papilosum and $S$. imbricatum, but they do correlate with $S$. cuspidatum, which confirms observations from recent mosses (Chau 1979). Van Geel (1978) found maxima of B. sphagni spores at the transitions from drier to wetter conditions. In the Borsteler Moor, maxima of $B$. sphagni coincide with the first two Sphagnum spore maxima, whereas single spores occur throughout the oligotrophic section.

HdV 724 (Fig. 5E, F; Bakker, van Smeerdijk 1982) was documented for open water conditions similar to copepod spermatophores (HdV 28). In the Borsteler Moor, HdV 724 often corresponds with oligotrophic conditions.

Van Geel, Aptroot (2006) found spores of Gelasinospora sp. (Fig. 5H; van Geel 1978: HdV 1) in highly decomposed peat, formed under dry, oligotrophic conditions and with the occurrence of charcoal. Lundqvist (1972) note that Gelasinospora species are mainly coprophilous, but also carbonicolous and lignicolous. In the Borsteler Moor, Gelasinospora sp. occurs together with Gelasinospora retispora Cain (Fig. 5G; van Geel 1978: HdV 2) and Neurospora crassa Shear \& B.O. Dodge (van Geel 1978: HdV 55C) in layers rich in microcharcoal and charred Sphagnum leaves (Fig. 4F), emphasizing their value as an indicator for dry phases during the development of oligotrophic Sphagnum peat (zone Borstel-4).

Black spores of 25-26 $\times 21-22 \mu \mathrm{m}$ with a truncate base (Fig. 5I), described as HdV 461 (Kuhry 1985), are morpho- 

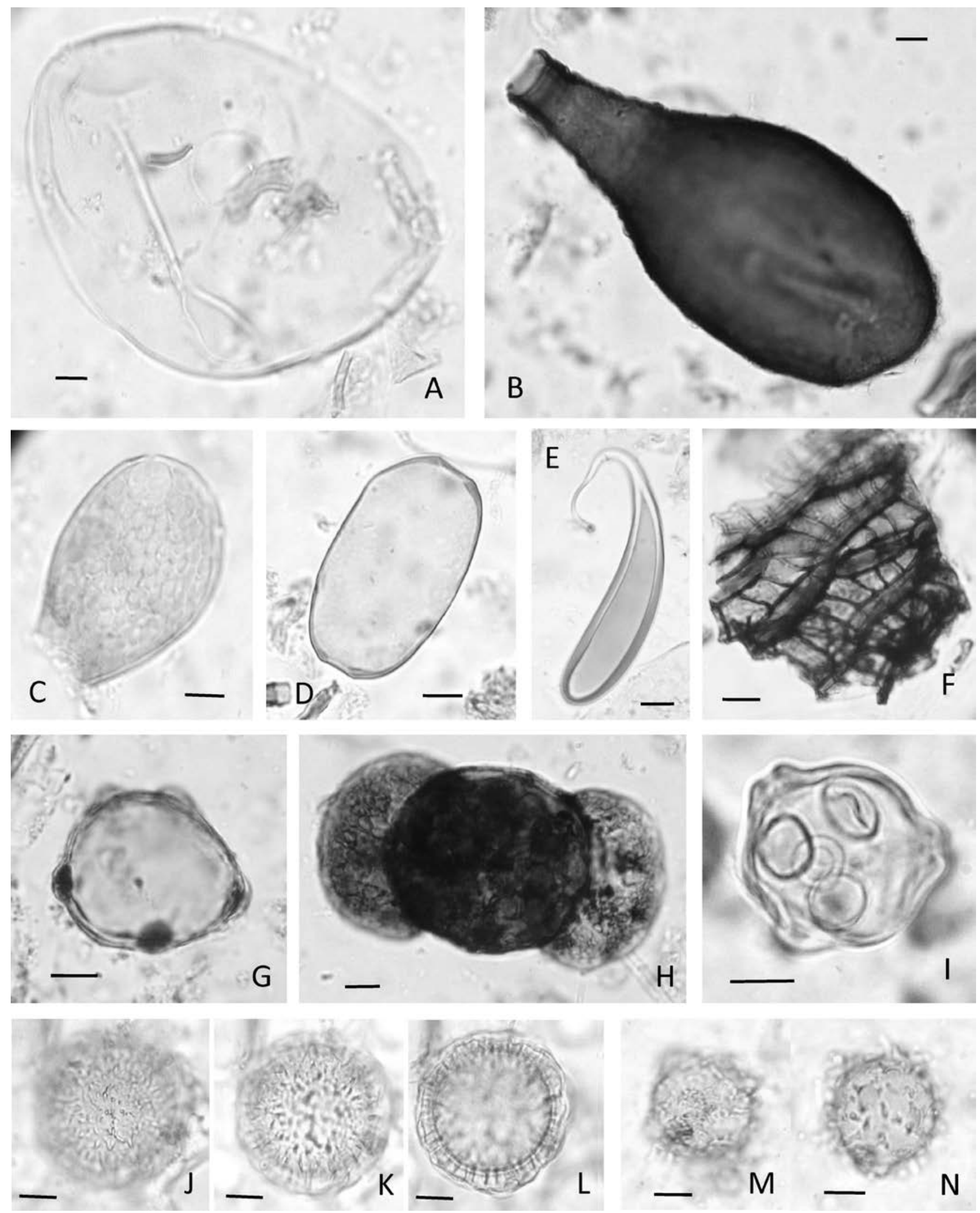

Fig. 4. A Arcella sp. (26 cm), B Habrotrocha angusticolis lorica $(20 \mathrm{~cm})$, C Assulina muscorum (16 cm), D Amphitrema flavum (18 cm), E spermatophore of copepods (6 cm), F charred Sphagnum leaves $(6 \mathrm{~cm})$, G Carpinus betulus infected by dark-coloured hyphae (4 cm), H Pinus diploxylon-type with inner covered by dark-coloured hyphae $(38 \mathrm{~cm})$, I Betula pollen with chytridiomycetes sporangia $(96 \mathrm{~cm}), \mathrm{J}-\mathrm{L}$ BM-1 $(10 \mathrm{~cm}), \mathrm{M}-\mathrm{N}$ HdV $59(4 \mathrm{~cm})$. Bar scale $10 \mu \mathrm{m}$. The indication in $\mathrm{cm}$ refers to the position in the core. 

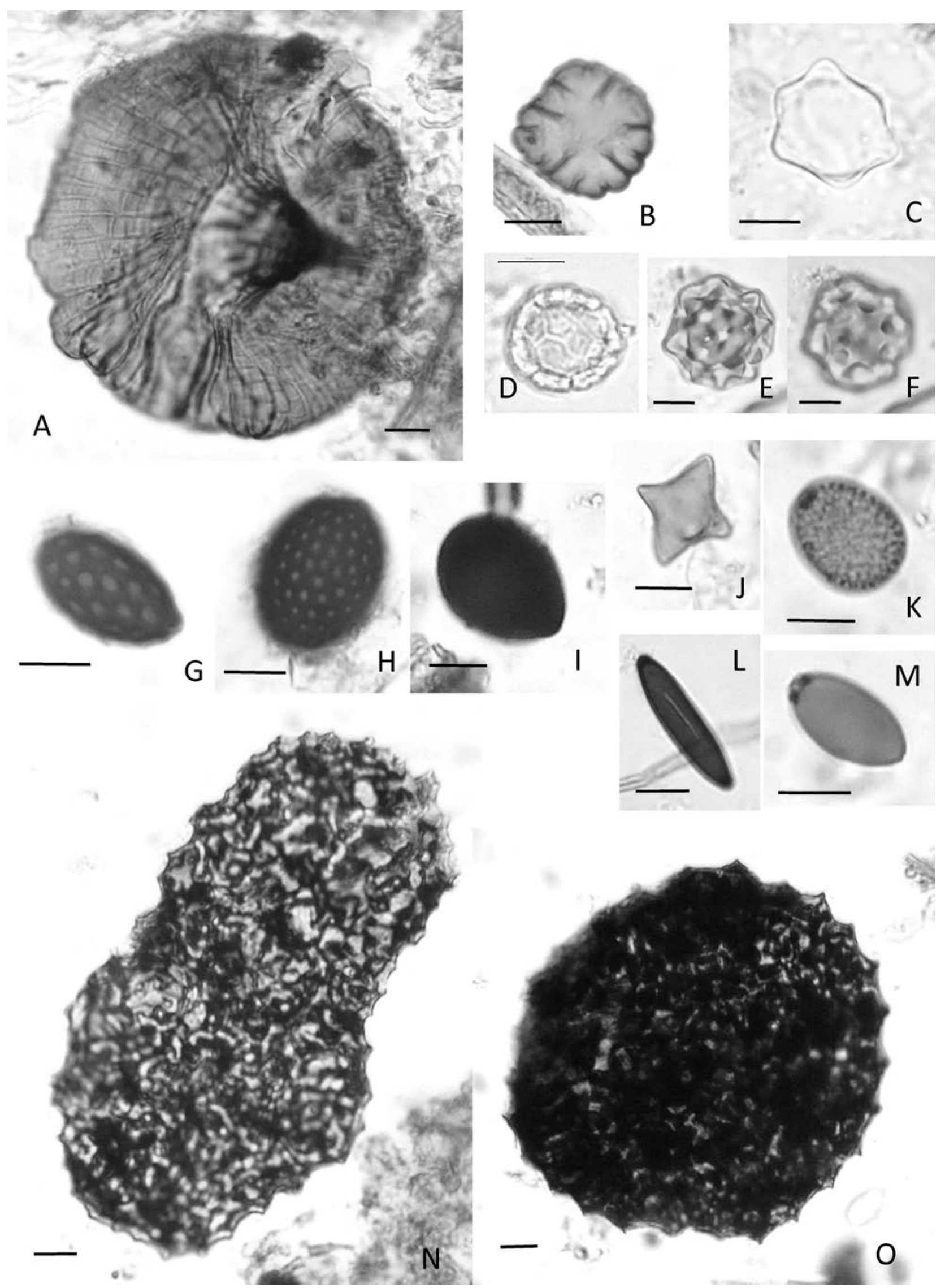

Fig. 5. A Fruiting-body of HdV 8D (56 cm), B HdV 13 Desmidiospora $(4 \mathrm{~cm}), \mathrm{C}$ HdV 66 cf. Inocybe sp. (6 cm), D Bryophytomyces sphagni $(50 \mathrm{~cm})$, E-F HdV $724(30 \mathrm{~cm})$, G Gelasinospora retispora $(6 \mathrm{~cm})$, H Gelasinospora sp. $(4 \mathrm{~cm})$, I Acrogenospora sphaerocephala $(112 \mathrm{~cm}), \mathrm{J} H d V 365 \mathrm{cf}$. Inocybe sp. (104 cm), K HdV $733(10 \mathrm{~cm}), \mathrm{L}$ Ustulina deusta $(26 \mathrm{~cm}), \mathrm{M}$ Podospora sp. (30 cm), N-O zygospores of Mucor sp. (BM-5) (38 and $30 \mathrm{~cm}$, respectively). Bar scale $10 \mu \mathrm{m}$. The indication in $\mathrm{cm}$ refers to the position in the core. 
logically similar to Acrogenospora sphaerocephala (Berk. \& Broome) M.B. Ellis or Acrogenospora ovalia Goh, K.D. Hyde \& K.M. Tsui (Ellis, Ellis 1985, Goh et al. 1998, Seifert et al. 2011). A. sphaerocephala (teleomorph Farlowiella) is a saprobic fungi of worldwide distribution (Goh et al. 1998) growing on the rotten wood of Acer, Alnus, Betula, Cornus, Prunus spinosa, Quercus, Sambucus, Taxus (Ellis, Ellis 1985), submerged Phragmites culms (Goh et al. 1998) as well as on other fungi (Seifert et al. 2011). As A. ovalia is known only for Hong Kong (Goh et al. 1998), HdV 461 might be related here to ascospores of $A$. sphaerocephala. Similar to the Amtsven section (Kuhry 1985), our findings are restricted to the humic sand layer at the base of the core and might indicate the presence of rotten wood.

Similar to HdV 66, spores of another species of Inocybe can be considered as the origin of HdV 365 (Fig. 5J; van Geel et al. 1981), which occurs in the Borsteler Moor during the mesotrophic stage.

HdV 733 (Fig. 5K) was first described from mesotrophic peat (Bakker, van Smeerdijk 1982). In the Borsteler Moor, HdV 733 is present at low frequencies during the mesotrophic stage and reaches its maximum of $5 \%$ during a dry hummock phase, but also occurs during hollow phases.

Ustulina deusta (Kretzschmaria deusta, Fig. 5L) is an ascomycetous plant pathogen causing soft-rot of living wood and contributing to decay after the host tree death (van Geel 1978: HdV 44). It was described from Fagus and regularly occurs on a variety of tree taxa such as Abies, Acer, Aesculus, Alnus, Betula, Carpinus, Castanea, Fraxinus, Populus, Quercus, Salix, Taxus, Tilia and Ulmus (van Geel 1978, Ellis, Ellis 1985). In the Borsteler Moor, spores of $U$. deusta are present throughout indicating the lasting presence of host trees or dead wood in the immediate vicinity. The spores are more common during the swamp conditions before the bog development, when Quercus trees were growing in the area.

The swamp-bog transition assemblage includes ascospores of Cercophora sp., Coniochaeta lignaria, Podospora sp. (Fig. 5M); Delitschia sp. (Fig. 6C) and Sordaria sp., which belong to mostly facultative coprophilous groups, including some species that also grow on other kinds of decaying organic material (Lundquist 1972, Richardson 2001, Krug et al. 2004).

Type IBB-18 (Montoya et al. 2010) is morphologically similar to the dark-brown 11-13(17) $\times 8-10 \mu \mathrm{m}$ ascospores of Podospora curvispora (Cain) Cain, which are strongly curved, concave on one side and convex on the other, with an apical germ pore of $1 \mu \mathrm{m}$ in diameter (Mirza and Cain 1969). P. curvispora is similar to Podospora selenospora Stchigel, Guarro \& M. Calduch; however, the latter has a germ pore on the convex side of the spore (Stchigel et al. 2002). In contrast to most other Podospora species, $P$. curvicola grows on decaying plant substrates other than dung (Mirza, Cain 1969). In the Borsteler Moor, $P$. curvispora is present in the lowest sandy peat (Borstel-1) together with other decaying fungi (Fig. 3b).

BM-5 (Fig. 5N, O) are round to elongated brown to dark-brown objects of 73-137 $\mu \mathrm{m}$ with $2-4 \mu \mathrm{m}$ protuberances at regular intervals of $8-13 \mu \mathrm{m}$ from each other. This type is similar to Mucor-type zygospores, especially the pigmented zygospores of e.g. Mucor hachijoensis Watanabe and M. meguroense Watanabe or of Zygorhynchus moelleri Vuill. (Watanabe 2010).

Spores of Anthostomella fuegiana Speg. (van Geel 1978: HdV 4) are suggested as indicators of the local presence of Eriophorum vaginatum plants (van Geel 1978, Kuhry 1985). In the Borsteler Moor, A. fuegiana spores are more common in the Sphagnum peat with Eriophorum. However, the correlations of the plant remains and fungus maxima are rather weak, whereas Cyperaceae pollen and $A$. fuegiana spores show a negative correlation.

BM-2 (Fig. 6A) are 3-celled rhomboid fungal spores, $27-28 \times 10-12 \mu \mathrm{m}$. The upper two brown-coloured cells are divided by a septum with a dark-brown rim of 6-7 $\mu \mathrm{m}$ breadth and the lower cell is hyaline with a pore of $1 \mu \mathrm{m}$. As BM-2 coincides with maximum of wood-decaying fungal spores, the type might represent conidiospores of saprotrophic fungi.

Van Geel (1978) correlated findings of HdV 83 (Fig. $6 \mathrm{~B}$ ) with those of type $\mathrm{HdV} 106$, a representative of relatively wet, oligotrophic bog conditions later identified as eggs of the oribatid mite Rhysotritia ardua (C.L. Koch) (Bakker, van Smeerdijk 1982). In the Borsteler Moor, HdV 83 occurs more often especially in wet phases of the Sphagnum peat (Borstel-4).

HdV 359 (van Geel et al. 1981) and HdV 462 (Kuhry 1985) are morphologically very similar and assumed to represent phragmoconidia of Brachysporium species like $B$. obovatum (Berk.) Sacc. and B. bloxami (Cooke) Sacc. or of Bactrodesmium betulicola M.B. Ellis (van Geel et al. 1981, Kuhry 1985). Finds in the Borsteler Moor (Fig. 6D) are most similar to spores of Brachysporium bloxami, a fungus living on the decaying wood of Acer, Alnus, Betula, Castanea, Fagus, Fraxinus, Pinus, Prunus, Quercus (Ellis, Ellis 1985), or to spores of Brachysporium brevius Hol.-Jech., which is an anamorphic stage of Cryptadelphia brevior Réblová \& Seifert and is known from decayed wood of Fagus sylvatica (Réblova, Seifert 2004). In agreement with the findings of Kuhry (1985), this type occurs in the humic sandy material (zone Borstel-2), but also occasionally during dry oligotrophic phases.

HdV 360 was also attributed to the genus Brachysporium (van Geel et al. 1981) and described as a fungal spore of 19-22 × 14-17.5 $\mu \mathrm{m}$ excluding the hyaline cells (1-3) situated at either end. The spore body is strongly pigmented, with a granulated inner wall side, and sometimes a hyaline "episporium" is seen. This type (Fig. 6E) is very similar in morphology and size to conidiospores of Brachysporium pendulisporum $\mathrm{S}$. Hughes, which are fusoid to limoniform, overall $30-42.5 \times 15-17.5 \mu \mathrm{m}, 4-5$-septate, with a brown to darkbrown central cell that is separated by thick septa from the small hyaline polar cells (Réblova, Seifert 2004; Markovskaja, Treigien 2007). B. pendulisporum (anamorph of Cryptodelphia pendulispora Réblová \& Seifert) is known from decaying wood from North America, Canada, and Eastern Europe (Markovskaja, Treigien 2007). Our findings and those of van Geel et al. (1981) indicate that this fungus also existed in Germany and the Netherlands during the Holocene.

The swamp-bog transition assemblage includes uredospores and teleutospores of the Puccinia-type (Fig. 6F; van Geel et al. 1981: HdV 357). 

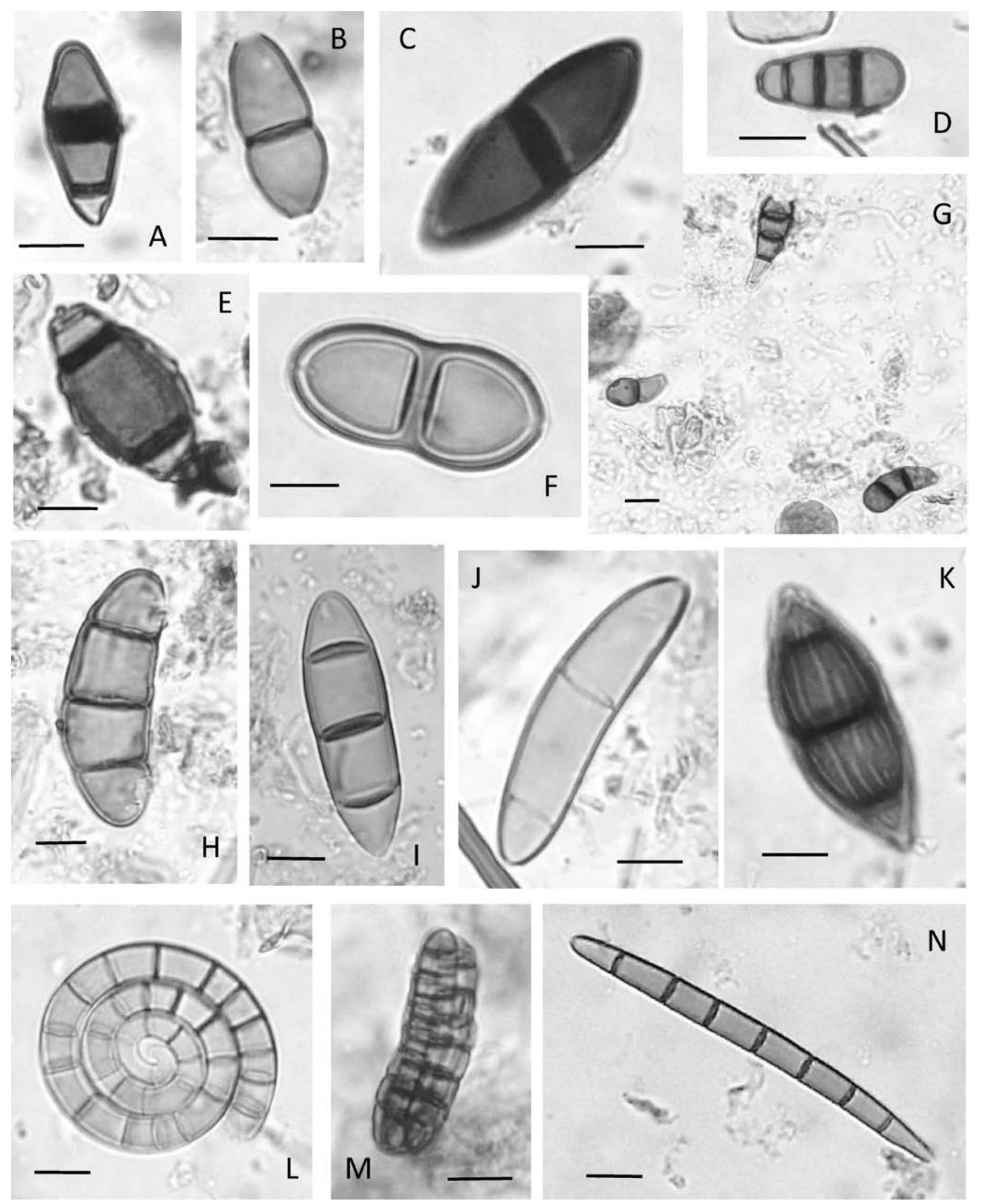

Fig. 6. A BM-2 $(96 \mathrm{~cm}), \mathrm{B} \mathrm{HdV} 83(14 \mathrm{~cm})$, C Delitschia sp. $(84 \mathrm{~cm})$, D Brachysporium bloxami $(84 \mathrm{~cm})$, E Brachysporium pendulisporum $(96 \mathrm{~cm}), \mathrm{F}$ Puccinia-type (38 cm), G HdV $10(4 \mathrm{~cm}), \mathrm{H}$ Meliola ellisii $(4 \mathrm{~cm}), \mathrm{I} \mathrm{HdV} 20 \mathrm{~d}(4 \mathrm{~cm}), \mathrm{J}$ BM-3 (32 cm), K HdV 463 (108 cm), L Helicoon pluriseptatum $(52 \mathrm{~cm})$, M Dictiosporium australiense (BM-4) $(112 \mathrm{~cm})$, N Geoglossum sphagnophilum $(40 \mathrm{~cm})$. Bar scale $10 \mu \mathrm{m}$. The indication in $\mathrm{cm}$ refers to the position in the core. 
A strong correlation of HdV 10 (Fig. 6G) with Calluna vulgaris pollen, seeds, leaves and possibly roots has been demonstrated in several records (van Geel 1978). HdV 10 is therefore a good indicator of locally dry conditions in raised bog peats (e.g. van Geel 1978, Kuhry 1985). HdV 10 can also correlate with Erica tetralix remains (Bakker, van Smeerdijk 1982). In the Borsteler Moor, this type occurs during increases of Calluna vulgaris pollen.

Another fungal spore associated with Calluna vulgaris is the ascomycete Meliola ellisii Roum (Fig. 6H), which was suggested to have been a common parasite on C. vulgaris in peat bogs during the Atlantic to Subatlantic period (van Geel 1978: HdV 14). In the Borsteler Moor, spores of Meliola ellisii are characteristic for Sphagnum peat, confirming that Calluna vulgaris growing on mineral soils is not infected (van Geel 1978). Moreover, maxima of Meliola ellisii occur during the wet phases, suggesting that Calluna vulgaris is less resistant to parasites under stressful wet conditions. Higher numbers of spores of the Meliola ellisii hyperparasite Isthmospora spinosa F. Stevens (van Geel et al. 2006) coincide with a small maximum of Meliola ellisii (Fig. 3b).

HdV 20d (Fig. 6I) is characterized by tapering apical ends, in contrast to the three-septate ascospores of HdV 20 (van Geel 1978). Van Geel (1978) suggested Empetrum as possible host of HdV 20. In the Borsteler Moor, HdV 20d occurs in low frequencies during the oligotrophic phase.

BM-3 (Fig. 6J) is a 3-4-septate, pale, slightly curved fungal spore of 51-52 $\times 10 \mu \mathrm{m}$, with rounded ends, each end with an apical pore of $1.5 \mu \mathrm{m}$. The septa are very thin, sometimes displaced or dissolved. In the Borsteler Moor, BM-3 occurred in just one sample $(34 \mathrm{~cm})$ during a wet phase of the oligotrophic stage.

We also found HdV 463 (Fig. 6K) described from the Amtsven section (Kuhry 1985) and assumed to be a Stuartella species. Following the figures in Müller (1962), this identification might be doubtful.

Helicoon pluriseptatum van Beverwijk (Fig. 6L) is known from peat bogs and marshy places on birch leaves, pine needles, pine cones, leaves of red oak, and grass blades (Van Beverwijk 1954 in van Geel 1978: HdV 30). In the Borsteler Moor, H. pluriseptatum is restricted to the first wet Sphagnum phase.

Type BM-4 (Fig. 6M) has pale brown conidia of $38-40 \times$ 10-12 $\mu \mathrm{m}$, consisting of one truncate cell with 3 vertical straight or slightly curved cylindrical 8-septate arms of more or less similar length, arranged close to each other. Morphologically, the type is very similar to Dictyosporium australiense Sutton 1985 (Sutton 1985, Goh et al. 1999). Smoothwalled, euseptate conidia produced from determinate conidiogenous cells is a generic characteristic of the whole genus Dictyosporium (Goh et al. 1999). These hyphomycetes occur worldwide on dead wood, decaying leaves and palm material. The teleomorphic stage is unknown. The systematic identification of species is based on their specific conidiospores (Goh et al. 1999), and allows the identification of this type to Dictyosporium australiense, known from dead wood (Goh et al. 1999). The spores of this fungus occur together with other decaying fungi in zone Borstel-2. Spores of the genus Dictyosporium (but another species, D. cf. heptasporum $=\mathrm{HdV} 1053$ ) were identified in a palaeoecological context from Lake Challa in southeastern Kenya (van Geel et al. 2011).

Geoglossum sphagnophilum Ehrenb. (Fig. 6N) is reported to grow among Sphagnum and its spores were found with Sphagnum remains (van Geel 1978: Type 77A). The spores were encountered from the Atlantic and Subboreal periods, especially in the upper parts of hummocks, just before the wet Scheuchzeria palustris overgrowing phases and in a layer characterized by Scheuchzeria palustris, Oxycoccus palustris and Andromeda polifolia (van Geel 1978). In the Borsteler Moor, G. sphagnophilum maxima occur during dry phases rich in Vaccinium-type.

Ascospores of Lasiosphaeria caudata (Fuckel) Sacc. (van Geel 1978: HdV 63A) were recorded with low frequencies in Holocene raised bog deposits (van Geel, Aptroot 2006). L. caudata grows on decaying wood of Picea (Munk 1957 in van Geel 1978) and its spores correlate to the most recent rise of Picea pollen in a raised bog in Denmark, underlining a host-parasite relationship (van Geel and Aptroot 2006). The presence of Picea pollen together with $L$. caudata spores in the Borsteler Moor suggests the presence of spruce relatively close to the site. This contrasts with the general view of a very late distribution of Picea in northern Germany caused by forestry management. Nevertheless, subfossil wood of Picea in Sphagnum peat of Lower Saxony (Leuschner, unpubl.) underline a much earlier presence of spruce.

HdV 350 (van Geel et al. 1981) occurs in the Borsteler Moor under mesotrophic conditions. Van Geel et al. (1981) found this type mainly in a layer rich in the mycorrhizal roots of Pinus.

\section{THE PALYNOLOGICAL DIAGRAM}

The palynological diagram was divided in four local pollen zones (Fig. 3a, b).

The lowest zone Borstel-1 (116-98 cm; 7.2-6.8 kyr $\mathrm{BP})$ is characterized by the dominance of Alnus (31-44\%), Quercus robur-type (19-35\%) and Corylus (14-27\%), accompanied by Sorbus group and Frangula alnus (Fig. 3a), indicating presence of an open oak forest in the wider surroundings and a swamp with mesotrophic conditions at the core site. Occurrence of pollen clumps of Quercus roburtype suggests the presence of oaks at the core site. NAP does not exceed $2 \%$, indicating only a small role of herbs in the ground vegetation, mainly represented by Melampyrum and accompanied by ferns (3\%). The fungal assemblages consist of HdV 461, 359/462, 463, 360 and the Delitschia-type (Fig. $3 \mathrm{~b}$ ), indicating presence of decaying wood. Sphagnum spores are very rare.

In the zone Borstel-2 (98-78 cm; 6.8-6.3 kyrs BP), percentages of Alnus reach a maximum of $53 \%$, Betula and Pinus increase up to 29 and 7\%, respectively, and Quercus robur type (4-18\%) and Corylus (8-16\%) decrease to the end of the zone (Fig. 3a). The spread of the pioneer species Betula possibly reveals leaching of soils or an increase in the ground water level. Pollen clumps suggest the presence of Quercus, Betula and Frangula alnus at the core site. The presence of open water at the site is indicated by copepod spermatophores (Fig. 3b). The presence of pollen of the Sorbus group, Frangula alnus, Melampyrum and of fern spores and 
fern sporangia accompanied by the fungal spores HdV 359/ 462 and 463 suggest a swamp with mesotrophic conditions similar to the previous zone. However, more frequent occurrence of Sphagnum spores accompanied by sphagniphilous indicators such as Amphitrema flavum and Habrotrocha angusticollis (Fig. 3b) points to the presence of Sphagnum mosses at the core site and the possible spread of Sphagnum peat in the area.

The zone Borstel-3 (78-66 cm; $6.3-5.9$ kyrs BP) is characterized by an increase of Pinus diploxylon-type from 4 to $20 \%$ and of Corylus from 12 to $20 \%$ and by the decrease of Betula from 39 to 20\% (Fig. 3a). Frangula alnus, Sorbus group, fern spores as well as fungal assemblages of the previous zones disappear, clearly indicating a change in the environmental conditions. Spermatophores of copepods and Rhabdocoela oocytes indicate open water conditions at the site (Fig. 3b). A slight increase in Calluna vulgaris, Cyperaceae and Sphagnum indicate the further development of Sphagnum peat. The fungal assemblages change considerably and now consist of Antostomella fuegiana (HdV 4), HdV 13, Cercophora, Coniochaeta, Podospora-type (Fig. 3b). HdV 59 reaches its maximum of $105 \%$.

Zone Borstel-4 (66-0 cm; 5.9-4.5 kyrs BP) is dominated by Alnus (25-37\%), Corylus (12-34\%), Quercus robur-type (6-20\%). Percentages of Betula and Pinus diploxylon-type vary between 3 and 11\% (Fig. 3a). The Pinus diploxylon-type maximum of $35 \%$ at $35 \mathrm{~cm}$ depth might be explained by a local presence of pine, as indicated by the occurrence of corresponding pollen clumps. Calluna vulgaris plays an important role in the zone, increasing from $1-5 \%$ in the lower to $10 \%$ in the upper part. A maximum of $24 \%$ of Calluna vulgaris at $24 \mathrm{~cm}$ core depth suggests the local presence of heathland plants. Besides Calluna vulgaris, additional ericaceous pollen of Vaccinium-type and Empetrum/ Ledum indicate raised bog conditions. Cyperaceae reach up to $10 \%$, possibly indicating the local presence of Eriophorum vaginatum. Furthermore, the zone Borstel-4 is characterised by pollen of Picea, Taxus, Fagus and Carpinus betulus as well as of many herbs such as Artemisia, Chenopodiaceae, Plantago lanceolata-type, Cerealia-type, Rumex acetosatype and Ranunculus acris-type. Such increased diversity of arboreal and non-arboreal pollen can be explained by increased anthropogenic influence in the region and/or more open conditions by the spreading peat bog and therefore more long-distance transport signals.

The zone Borstel-4 is rather heterogeneous. NPP grouping reveals four dry and three wet phases during the period (Fig. 3b). Dry phases occur at 66-53 cm (5.9-5.7 kyrs BP), 45-37 cm (5.5-5.3 kyrs BP), 31-17 cm (5.1-4.8 kyrs BP) and $9-0 \mathrm{~cm}(4.6-4.5 \mathrm{kyrs}$ BP) and are characterized by higher percentages of microcharcoal (up to 15,000 particles / $\mathrm{cm}^{3}$ ), fungal spores such as $\mathrm{HdV} 4,10,13$, Gelasinospora, but also Lasiosphaera caudata as well as of HdV-59 and pollen with dark-coloured hyphae (Fig. 3b). The wet phases at 53-45 cm (5.7-5.5 kyrs BP), 37-25 cm (5.3-5 kyrs BP) and 21-9 cm (4.9-4.6 kyrs BP) are characterized by the dominance of Sphagnum spores, the parasitic fungus Bryophytomyces sphagni, testate amoebae Amphitrema flavum, Assulina, Arcella, and rotifer loricae of Habrotrocha angusticolis (Fig. 3b).
The oligotrophic conditions started at $\sim 6 \mathrm{kyrs}$ BP with a relatively dry phase indicated by Calluna vulgaris and Vaccinium-type, fungal spores of Meliola ellisii and HdV 10. Furthermore, this phase is characterized by a fungal assemblage including ascospores of Gelasinospora, Cercophora, Coniochaeta lignaria, Podospora and Sordaria (Fig. 3b). Pollen grains with dark-colored hyphae reach their first maximum of $14 \%$. Large amounts of fungal remains indicate increased saprotrophic activity.

At $\sim 5.7$ kyrs BP, the community with Sphagnum and sphagnophilous indicators such as Amphitrema, Habrotocha angusticollis and Sphagnum pathogen Brachyosporium sphagni indicate the establishment of relatively wet conditions (Fig. 3b). This phase lasted $\sim 180$ years until 5.5 kyrs $\mathrm{BP}$, and was replaced by a dry community with Vaccinium, Calluna vulgaris and Cyperaceae (possibly Eriophorum vaginatum) (Fig. 3a). Similar to the first dry phase, the second is again characterized by an increase of saprotrophic fungal remains and pollen attacked by fungi. Copepod spermatophores indicate the (temporary) presence of open water at the site.

The second Sphagnum phase at 5.3-5 kyrs BP is characterized by lower numbers of testate amoebae but also the presence of the Calluna vulgaris parasite Meliola ellisii and its hyperparasite Isthmospora spinosa (Fig. 3a). The end of this wet phase overlaps in the diagram with the third dry phase 5.1-4.8 kyrs BP. Calluna vulgaris dominated the vegetation again, the local presence of which is indicated by HdV 10. Higher charcoal concentrations (up to 7,600 particles $/ \mathrm{cm}^{3}$ ) together with fungal spores and pollen attacked by fungi indicate drier conditions with fires as well as increased saprotrophic activity.

The last Sphagnum phase (4.9-4.6 kyrs BP) overlaps with the prevailing relatively dry phase. This Sphagnum phase is characterized by the same NPP assemblages as the previous wet phase but lacks Bryophytomyces sphagni and contains a large amount of $\mathrm{HdV} \mathrm{10,} \mathrm{indicating} \mathrm{the} \mathrm{presence}$ of Calluna vulgaris (Fig. 3a, b). The pollen spectra of the youngest documented dry phase (4.6-4.5 kyr BP) are characterized by high values of Calluna vulgaris and Cyperaceae as well as by maxima of microcharcoals, saprotrophic fungal spores, pollen attacked by fungi and type BM-1.

\section{DISCUSSION}

The Borsteler Moor core contains a high diversity of NPP, including 6 animal, 3 plant, 34 fungal and 3 unknown types. The higher numbers of the fungal remains is likely to be explained by their greater resistance to environmental chemical and biological degradation as well as to laboratory treatments.

The diverse and numerous fungal remains form distinct fungal assemblages corresponding to mesotrophic and oligotrophic stages. Even though the prevalence of well-preserved spores and the lack of thin-walled hyaline specimens mean that our understanding of the former fungal communities is limited, we can nevertheless analyze trends in the fungal fossil assemblages. During the mesotrophic stage, the assemblage contains a variety of soil and wood decay fungi such as Brachysporium bloxami, Brachysporium pendulisporum, Podospora curvispora, Dictyosporium australiense, Acro- 
genospora sphaerocephala. These fungi are present in zones Borstel-1 and 2 and disappear in zones Borstel-3 and 4, which could be explained either by disappearance of suitable substrate or a change in environmental conditions or both. The changes in the fungal assemblages clearly correspond to changes in the pollen composition. Mesotrophic fungal communities correlate well with the presence of Quercus, Betula and Frangula alnus on site, revealed by occurrence of their pollen clumps (Fig. 3a). With the development of heathland and Sphagnum peat bog, the substrate changes considerably and includes degradation-resistant sclerophyllous species. In combination with the high water content and acidification caused by Sphagnum, this leads to the restriction of the "decomposer" community from the lignicolous to mainly facultative coprophilous communities represented by Podospora, Cercophora, Coniochaeta, Gelasinospora, Neurospora. These fungi profit from dung, which contains a high concentration of available nutrients, but they can also decompose other organic substrates as well (Krug et al. 2004). Such a large change in the assemblage of fungal decomposers indicates an important change in the nutrient status of the ecosystem, which obviously became more dependent on nutrient inputs from outside because organic material cannot be easily decomposed any more. This could be the reason for increased hyphal attack on pollen, as this provides easily available nutrients in large quantities in spring (Shumilovskikh et $a l$. in revision). This trend is additionally seen by the fact that diversity of the oligotrophic assemblage increases mainly through parasitic fungi such as Bryophytomyces sphagni, Geoglossum sphagnophilum, Meliola ellissii, Isthmospora spinosa, Lasiosphaeria caudata, Anthostomella fuegiana, clearly indicating the presence of their hosts (van Geel 1978, van Geel and Aptroot 2006). In general, the fungal assemblage of the oligotrophic stage is more diverse and consists of fungi occurring in either (1) dry or (2) wet phases and of (3) fungi of all moisture levels. The oligotrophic dry phase assemblage is indicated by the presence of charcoal and carbonifilous fungi (Gelasinospora sp., Gelasinospora reticulispora, Neurospora) as well as by fungi associated with Calluna vulgaris such as type 10, Meliola ellisii and Isthmospora spinosa (van Geel 1978). The oligotrophic wet phase assemblage includes mainly parasitic fungi Bryophytomyces (Tilletia) sphagni growing on Sphagnum (Fig. 3b).

Chronologically, the development of the bog at the Borsteler Moor site started with an accumulation of organic material on sand at $\sim 7.1$ kyrs BP, most probably due to an increase in the water table caused by a rising sea-level (Behre 2004). Pollen data suggest the presence of an oak forest with hazel, alder and Frangula alnus until 6.7 kyrs BP, when the first $15 \mathrm{~cm}$ of the humic layer accumulated. This mesotrophic peat was covered by ferns, possibly Rubus (Sorbus group) and Melampyrum. The remains of decomposer and soil fungi indicate soil development, and high pollen concentrations reveal a high decomposition rate at the site. A further increase in the water table and the growing Sphagnum peat led to the degradation of the oak forest and the spread of the pioneer trees Betula and Pinus (6.7-6.2 kyrs BP). Percentage maxima of decaying fungi as well as their high concentrations of up to 20,000 spores $/ \mathrm{cm}^{3}$ (not shown) suggest the presence of dead wood, which possibly was an important source of peat formation. Between 6.2 and 6 kyrs BP, a Pinus-Betula carr replaced a Betula-Quercus forest. Rubus and Frangula alnus disappeared and ferns decreased. The light levels increased and Cyperaceae, Poaceae, Calluna vulgaris and possibly mosses (type BM-1) became more abundant. A further increase of the water table led to at least the temporary presence of open water at the site after $\sim 6.1 \mathrm{kyrs}$ BP. Typical bog vegetation spread and started to build a raised bog from $\sim 6 \mathrm{kyr} B P$ onwards. Thereby, the succession proceeded as an alternation between dry $(6-5.7,5.5-5.3,5.1-4.8,4.6-4.5$ kyrs BP) and wet (5.7-5.5, 5.3-5, 4.9-4.6 kyrs BP) phases. During the dry phases the strong increase in spores of decaying fungi confirms observations of previous palaeoecological investigations about increased fungal activities and accelerated decomposition rates (e.g. van Geel 1978; Bakker, van Smeerdijk 1982; Kuhry 1985; Middeldorp 1986; Willemsen et al. 1996).

Considering pine germination and die-off phases, it is possible to suggest that the establishment of pines could occur during these dry and nutrient-rich phases. However, percentage (Fig. 3a) and concentration (not shown) maxima of Pinus pollen as well as AP in general do not clearly correlate with dry or wet phases. There are multiple possible reasons for this mismatch of dry phases in bog development and pine establishment, and their discussion goes beyond of the scope of the present paper.

In summary, our palynological study of the sediment core from the Borsteler Moor clearly reveals a change from mesotrophic to nutrient-poor conditions at $\sim 6$ kyrs BP, coinciding with vegetation development from oak forests to Calluna heathland and Sphagnum peat. According to the NPP, the establishment of Sphagnum peat was not gradual but it was interrupted by four dry phases, characterized by accelerated decomposition rates.

\section{Acknowledgement}

We thank Laura Sutcliffe for polishing the English and two anonymous reviewers for improving the manuscript. The study was supported by the DFG projects LE 1805 and HA 4439 as well as within the grant in accordance with Resolution of the Government of the Russian Federation No. 220 dated April 09, 2010, under Agreement No. 14.B25.31.0001 with Ministry of Education and Science of the Russian Federation dated June 24, 2013 (BIO-GEOCLIM).

\section{REFERENCES}

Bakker M., van Smeerdijk D.G. 1982. A palaeoecological study of a late Holocene section from "Het Ilperveld", western Netherlands. Review of Palaeobotany and Palynology 36, 95-163.

Bauch R. 1938. Über die systematische Stellung von Tilletia Sphagni Nawashin. Berichte der Deutschen Botanischen Gesellschaft 56, 73-85.

Behre K.-E. 2004. Coastal development, sea-level change and settlement history during the later Holocene in the Clay District of Lower Saxony (Niedersachsen), northern Germany. Quaternary International 112, 37-53.

Behre K.-E. 2008. Landschaftsgeschichte Norddeutschlands Umwelt und Siedlung von der Steinzeit bis zur Gegenwart. Wachholtz Verlag, Neumünster.

Beug H.-J. 2004. Leitfaden der Pollenbestimmung. Verlag Dr. Friedrich Pfeil, München. 
Bielańska-Grajner I., Cudak A., Mieczan T. 2011. Epiphytic rotifer abundance and diversity in moss patches in bogs and fens in the Polesie National Park (Eastern Poland). International Review of Hydrobiology 96, 29-38.

Blaauw M. 2010. Methods and code for 'classical' age-modeling of radiocarbon sequences, Quaternary Geochronology 5, 512518.

Blaauw M., Mauquoy D. 2012. Signal and variability within a Holocene peat bog - Chronological uncertainties of pollen, macrofossil and fungal proxies. Review of Palaeobotany and Palynology 186, 5-15.

Borradaile L.A., Eastham L.E.S., Potts F.A., Saunders J.T. 1963. The Invertebrata. Cambridge University Press, Cambridge.

Bradley W. H. 1967. Two aquatic fungi (Chytridiales) from the Green River Formation of Wyoming. American Journal of Botany 54, 577-582.

Chau R. 1979. Conidial ultrastructure and taxonomic affinity of a fungal parasite of Sphagnum. The Michigan Botanist 18, $15-18$.

Braune W., Leman A., Taubert H. 1999. Pflanzenanatomisches Praktikum II. Zur Einführung in den Bau, die Fortpflanzung und Ontogenie der niederen Pflanzen (auch der Bakterien und Pilze). Spektrum Verlag, Heidelberg, Berlin (in German).

Davey M.L., Currah R.S. 2006. Interactions between mosses (Bryophyta) and fungi. Canadian Journal of Botany 84, 1509-1519.

Eckstein J., Leuschner H.H., Bauerochse A. 2011. Mid-Holocene pine woodland phases and mire development - significance of dendrochronological data from subfossil trees from nortwest Germany. Journal of Vegetation Science 22, 781-794.

Eckblad F.-E. 1975. Tilletia sphagni, Helotium schimperi, or what? Pollen et Spores 17, 423-428.

Ellis M.B., Ellis J.P. 1985. Microfungi on land plants. The Richmond Publishing, Slough.

Frey D.G. 1964. Remains of animals in Quaternary lake and bog sediments and their interpretation. Ergebnisse der Limnologie $2,1-114 . \mathrm{M}$

Goh T.K., Hyde K.D., Tsui K.M. 1998. The hyphomycetes genus Acrogenospora, with two new species and two new combinations. Mycological Research 102, 1309-1315.

Goh T.-K., Hyde K.D., Ho W.H, Yanna 1999. A revision of the genus Dictyosporium, with descriptions of three new species. Fungal diversity 2, 65-100.

Grosse-Brauckmann G. 1997. Moore und Moornaturschutzgebiete in Deutschland - eine Bestandsaufnahme. Telma 27, 183-215.

Hesmer H. 1929. Mikrofossilien in Torfen. Paläontologische Zeitschrift $11,245-257$

Juggins S. 2007. C2. Software for ecological and palaeoecological data analysis and visualisation. User guide Version 1.5. University of Newcastle, Newcastle upon Tyne.

Kalgutkar R.M., Jansonius J. 2000. Synopsis of fossil fungal spores, mycelia and fructifications. AASP, Dallas.

Krug J.C., Benny G.L., Keller H.W. 2004. Coprophilous fungi. In Mueller G.M., Bills G.F., Foster M.S. (eds.), Biodiversity of Fungi: Inventory and Monitoring Methods, 467-499. Elsevier, Amsterdam

Kuhry P. 1985. Transgression of a raised bog across a coversand ridge originally covered with an oak-lime forest. Palaeoecological study of a Middle Holocene local vegetation succession in the Amtsven (northwest Germany). Review of Palaeobotany and Palynology 44, 303-353.

Kuhry P. 1997. The palaeoecology of a treed bog in western boreal Canada: a study based on microfossils, macrofossils and physic-chemical properties. Review of Palaeobotany and Palynology 96, 183-224.

Kürschner H., Shumilovskikh L., Djamali M., de Beaulieu J.-L.
2014. A late Holocene subfossil record of Sphagnum squarrosum Crome (Sphagnopsida, Bryophyta) from NW Iran. Nowa Hedwigia, 100, 373-381.

Lundqvist N. 1972. Nordic Sordariaceae sensu lato. Symbolae Botanicae Upsalienses 20, 1-314.

Markovskaja S., Treigien A. 2007. A new and a rare species of Cryptadelphia and their Brachysporium anamorphs. Nova Hedwigia 84, 495-501.

Middeldorp, A.A. 1986. Functional palaeoecology of the Hahnenmoor raised bog ecosystem - a study of vegetation history, production and decomposition by means of pollen density dating. Review of Palaeobotany and Palynology 49, 1-73.

Miola A. 2012. Tools for Non-Pollen Palynomorphs (NPPs) analysis: A list of Quaternary NPP types and reference literature in English language (1972-2011). Review of Palaeobotany and Palynology 186, 142-161.

Mirza J.H., Cain R.F. 1969. Revision of the genus Podospora. Canadian Journal of Botany 47, 1999-2048.

Montoya E., Rull V., van Geel B. 2010. Non-pollen palynomorphs from surface sediments along an altitudinal transect of the Venezuelan Andes. Palaeogeography, Palaeoclimatology, Palaeoecology 297, 169-183.

Müller E. 1962. Über die Ascomycetengattung Stuartella Fabre. Berichte der Schweizerischen Botanischen Gesellschaft $=$ Bulletin de la Société Botanique Suisse / Band 72, 118-122.

Munk A. 1957. Danish Pyrenomycetes. Dansk Botamisk Arkiv 17, $1-491$.

Punt W., Hoen P.P., Blackmore S., Nilsson S., le Thomas A. 2007. Glossary of pollen and spore terminology. Review of Palaeobotany and Palynology 143, 1-81.

Réblová M., Seifert K.A. 2004. Cryptadelphia (Trichosphaeriales), a new genus for holomorphs with Brachysporium anamorphs and clarification of the taxonomic status of Wallrothiella. Mycologia 96, 343-367.

Richardson M.J. 2001. Diversity and occurrence of coprophilous fungi. Mycological Research 105, 387-402.

Reimer P.J., Bard E., Bayliss A., Beck J.W., Blackwell P.G., Bronk Ramsey C., Buck C.E., Edwards R.L., Friedrich M., Grootes P.M., Guilderson T.P., Haflidason H., Hajdas I., Hatté C., Heaton T.J., Hoffmann D.L., Hogg A.G., Hughen K.A., Kaiser K.F., Kromer B., Manning S.W., Niu M., Reimer R.W., Richards D.A., Scott E.M., Southon J.R., Turney C.S.M., van der Plicht J., 2013. IntCal13 and Marine13 radiocarbon age calibration curves, 0-50,000 years cal BP. Radiocarbon 55, 1869 1887.

Rudolph K. 1917. Untersuchungen über den Aufbau Böhmischer Moore. I. Aufbau und Entwicklungsgeschichte Südböhmischer Moore. Abhandlungen der K.K. zoologisch-botanischer Gesellschaft im Wien 9, 1-116.

Seifert K., Morgan-Jones G., Gams W., Kendrick B. 2011. The genera of Hyphomycetes. CBS Biodiversity Series 9. CBSKNAW Fungal Biodiversity Centre, Utrecht.

Sherwood-Pike M.A. 1988. Freshwater fungi: fossil record and paleoecological potential. Palaeogeography, Palaeoclimatology, Palaeoecology 62, 271-285.

Shumilovskikh L.S., Schlütz F., Achterberg I., Kvitkina A., Bauerochse A., Leuschner H.H. Pollen as nutrient source in Holocene ombrotrophic bogs. Review of Palaeobotany and Palynology, in revison.

Stchigel A.M., Calduch M., Guarro J., Zaror L. 2002. A new species of Podospora from soil in Chile. Mycologia 94, 554-558.

Sutton B.C. 1985. Notes on some deuteromycete genera with cheiroid or digitate brown conidia. Proceeding of Indian Academy of Science (Plant Science) 94, 229-244.

Van Beverwijk A.L. 1954. Three new fungi: Helicoon pluriseptatum n.sp., Papulaspora pulmonaria n. sp. and Tricellula 
inaequalis n.gen. n.sp. Antonie van Leeuwenhoek 20, 1-16.

Van Geel B. 1978. A palaeoecological study of Holocene peat bog sections in Germany and the Netherlands, based on the analysis of pollen, spores and macro- and microscopic remains of fungi, algae, cormophytes and animals. Review of Palaeobotany and Palynology 25, 1-120.

Van Geel B., Bohncke S.J.P., Dee H. 1981. A palaeoecological study of an upper late glacial and Holocene sequence from "de Borchert", the Netherlands. Review of Palaeobotany and Palynology 31, 367-448.

Van Geel B., Aptroot A. 2006. Fossil ascomycetes in Quaternary deposits. Nova Hedwigia 82, 313-329.

Van Geel B., Aptroot A., Mauquoy D. 2006. Sub-fossil evidence for fungal hyperparasitism (Isthmospora spinosa on Meliola ellisii, on Calluna vulgaris) in a Holocene intermediate ombrotrophic bog in northern-England. Review of Palaeobotany and
Palynology 141, 121-126.

Van Geel B., Gelorini V., Lyaruu A., Aptroot A., Rucina S., Marchant R., Damsté J.S.S., Verschuren D. (2011). Diversity and ecology of tropical African fungal spores from a 25,000year palaeoenvironmental record in southeastern Kenya. Review of Palaeobotany and Palynology 164, 174-190.

Warner B.G., Chengalath R. 1988. Holocene fossil Habrotrocha angusticollis (Bdelloidea: Rotifera) in North America. Journal of Palaeolimnology 1, 141-147.

Watanabe T. 2010. Pictorial Atlas of Soil and Seed Fungi. CRC Press, Boca Raton.

Willemsen J., van't Veer R., van Geel B. 1996. Environmental change during the medieval reclamation of the raised-bog area Waterland (The Netherlands): a palaeophytosociological approach. Review of Palaeobotany and Palynology 94, 75-100. 